\title{
Rosie - the quintessential Indian Woman in R. K. Narayan's "The Guide"
}

\author{
Gangotri Sil \\ M.A.The University of Burdwan, Govt. Assistant Teacher of English in Dahakula Junior High School
}

\begin{abstract}
This paper tries to observe the character of Rosie and trace the evolution that she goes through in the novel "The Guide" by R.K.Narayan. As a result of her bold actions, it is often thought that she is very different from common Indian women. I have tried to show that in reality she is just like our diverse Indian culture which conceives both tradition and modernity. Her desires, dilemmas and decisions can happen only to an Indian woman. She may seem ahead of her time but certainly contemporary in 2014. Thus even today's modern Indian women can identify themselves with Rosie. In fact her journey towards self establishment somehow forecasts the evolution of women's role in the Indian society. Rosie in this aspect stands as a quintessential Indian woman.
\end{abstract}

Key Words: Art, Culture, Hegemony, Identity, Revolution, Womanhood

The title of Narayan's first novel, "The Guide", shows that the protagonist is certainly Raju the famous guide of Malgudi. Yet the covers of most of the published manuscripts of "The Guide" have the portrait of a sari clad BharatNatyam dancer, undoubtedly Rosie. This small yet significant fact helps one to understand the impact of the character upon the minds of the readers. And the impression keeps on reverberating due to the complexity of Rosie's character. "I couldn't understand her"(Narayan, 119)- says Raju about Rosie in his narration to Velan.The readers of the novel too feel alike. She challenges the Hindu orthodox stereotype of how a woman should be and yet a part of her complex nature is intensely orthodox. In her we can see a woman trying desperately to free herself from the pigeonhole, at the same time allowing the doors of patriarchy to enclose her.

Significantly Rosie enters Malgudi through Railways which brings the touch of modernity with it to the traditional and homogenous culture of Malgudi. The exotic nature of her westernized name also shows her social hybridity. Raju use to wonder -

"Why did she call herself Rosie? She did not come from a foreign land. She was just an Indian, who should have done well with Devi, Meena, Lalitha or any of the thousand names we have in our country." (Narayan,9) (1)

But her name is only a starting point of her unorthodox life. She traditionally belongs to a Devdasi family who are dedicated to the temples as dancers. They are viewed in the society as of low class women. Yet she acquires a University degree, M.A. in Economics, which is not only unconventional but almost revolutionary. In fact Rosie reads ancient works on dancing such as Bharat Muni's Natya Shastra and even employs a pundit to explain the old Sanskrit verses. She also looks for ideas in the Ramayana and Mahabharata. Thus we realize that Rosie not only has bookish knowledge but can blend her knowledge with her art like a truly educated person. She marries a scholar and apparently broad minded person. But actually his only intention is to earn the name of a liberal and modern man. He never accepts Rosie's talent as a dancer and completely ignores her keen desire to continue her career in dance. For Rosie, like any true artist, dance is not only her passion but her way of reaching to God, her vocation. She never can calmly accept the insult of her art by Marco-

"An acrobat on a trapeze goes on doing the same thing all his life; well your dance is like that. What is there intellect or creative in it? You repeat your tricks all your life. We watch a monkey perform not because it is artistic but because it is a monkey that is doing it."( Narayan ,148)

Moreover Marco never treats her as a human being who has some individual expectations from her life. His male ego coupled with his pride of his knowledge makes him blind to the fact that Rosie is not an artifact to be put and showcased in the bed room. She is his wife who deserves a happy conjugal life. Marco is seen to be more interested in the sculptures on walls and stones in caves than in his wife who is a living embodiment of those images. Dead and decaying things attract his attention but not that which lives and laughs and dreams. Raju recalls in his narration how Rosie wishes to enjoy the small, simple joys of normal life -

"She liked to loaf in the market, eat in a crowded hotel, wander about, see a cinema-these common pleasures seemed to have been beyond her reach all these days."(Narayan, 84)

Naturally their marriage was in jeopardize. Som Dev rightly remarks -

"If Rosie is driven to the arms of a stranger, it is partly not her fault. Had he considered the basic needs of the woman he takes for a wife. He has offered insult to the womanhood and in turn womanhood in Rosie 
raise its hood to leave 'fangs marks' on him".(2)

Thus Rosie decides to leave her legal husband and starts living with another man, Raju. Such relationships are not much encouraged even in today's India and Rosie or may we more aptly say Narayan has the courage to do it in 1958.It is a country of the Sita-Savitris, the myths which Narayan has used in this novel too, where the good wives forgives all the mistakes of their husbands, gives agnipariksha to prove their physical purity. But Rosie shows the other way.

The most important aspect of Rosie's character is her pursuit of dance. As a Devdasi she learns to use it for professional gains. But for Rosie, as we can see, dance is far beyond any kind of material gains. At first it becomes her way to achieve spiritual sanctity which later becomes her means of gaining independent identity. Rosie as a dancer is associated with Cobra, the snake. Raju narrates the scene in which Rosie watches the king Cobra dance:

"The whole thing repelled me, but it seemed to fascinate the girl. She watched it swaying with the rapt attention. She stretched out her arm slightly and swayed it in imitation of the movement; she swayed her body to the rhythm for just a second..."(Narayan, 68)

Later, when she becomes a famous dancer, Rosie's greatest performance, her "masterpiece", is the snake dance. For a dancer in India, moreover, the snake has yet another connotation. In Hindu mythology the naga is also the emblem of the Cosmic Dancer, Shiva-Nataraja. Rosie dedicates herself to the God as the guardian of her art - in her home she dreams of having "a bronze figure of Nataraja, the God of dancers, the God whose primal dance creates the vibrations that set the worlds in motion." Her snake dance is formed to an ancient song which evokes and worships Shiva who is represented by the mythical Snake Rosie conjures up through her rippling gestures. The snake that resides on the locks of Shiva himself, on the wrist of his spouse, Parvati, and in the ever radiant home of the Gods in Kailash. This is a song that elevates the serpent and brings out its mystic quality... which lifts the Cobra out of its class of an underground reptile into a creature of grace and an ornament of the Gods." The image of the Cobra as the mystic symbol of Shiva is related to Rosie herself- she too, is from an "underground" or socially stigmatized class, and yet she can come close to the Gods through her dance, which for her is the sincerest form of worship. Even Raju admits--

"I could honestly declare while I watched her perform, my mind was free, for once, from all carnal thoughts. I viewed her as pure abstraction."(Narayan,125)

Thus within years Rosie alias Nalini becomes an extremely famous Bharat Natyam dancer. In a country where women are still harassed and questioned in their workplaces just for being women, this achievement of Rosie, to become a thoroughly welcomed and respected BharatNatyam dancer, to successfully pursue her art, to transform herself into a self-made woman is a revolution in itself.

In spite of all these, one part of her remains essentially orthodox. First of all she herself never really respects her own Devdasi clan and always calmly accepts what is publicly told about them- "we are viewed as public women. We are not considered respectable; we are not considered civilized." (Narayan, 84) Being a highly educated woman she should have tried to reform the image of her clan in the society or make people aware about the unfair system of the Devdasis. In fact Gayatri Chakroborty Spivac has charged Narayan with making Rosie the heroine of a sentimental tragicomedy rather than exposing through her situation the evils of the Devdasi system. (3) Again Rosie keeps on carrying the burden of her failed marriage all her life. First of all Rosie seems to have an extremely old fashioned notions about the relationship between husband and wife and about the role of women in society. She constantly expresses her gratitude to Marco for having married her in spite of her background. "After all, after all, he is my husband."(Narayan, 201) and it is far better to end one's life on his doorstep. We can also find her abiding sense of guilt at having betrayed his trust- "I realized I had committed an enormous sin."(Narayan, 150) Even after many years, when she becomes a household name with her own identity, her unsympathetic and insulting husband's book remains very dear to her and she carries it all her life. She knows very well her husband can never appreciate her art or womanhood. Then even her attitude towards the dominating and hard-hearted Marco remains one of submission and subservience. Moreover her change of name from Rosie to Nalini is a hint of her wish to fit herself in that very conventional society which she challenges and leaves. Nalini' means the lotus, the seat of the Goddess Lakshmi. According to Hindu Mythology Brahma too rests on a bed of lotus petals in a state of contemplation. Thus as the westernized name of Rosie marks out her state of social exclusion, through the name of Nalini, Rosie symbolically seeks an entry into the orthodox society that rejects her.

Thus we see that Rosie is caught in a contradiction between her dedication to dance and the cultural norms and values that are imposed upon her by the society. Rosie even can be seen as a result of Narayan's patriarchal hypocrisy. But as I have mentioned, to understand Rosie and her hesitations, one needs to take into account the various issues that are associated with her. First of all one must remember that she is one of the many important women characters of Narayan. Thus we need to locate Rosie in the gallery of Narayan's women in order to fully realize her predicament. "The Dark Room"(1938) is the story of Savitri, a middle class housewife who submits to the demands of patriarchy. (4) In "Mr. Sampanth" (1949) ,Shanti, the widowed 
actress and dancer whose trademark was her handbag made of cobra-hood complete with the spectacle like mark, becomes the mistress of Sampanth who is to bring her fame by casting her in a film. (5) In many ways, even down to the details of the story, Shanti seems to function as an anticipation of the far more fully developed character of Rosie. Unlike Savitri in "The Dark Room", When Rosie is rejected by her husband, she is able to sustain herself through her art, like Shanti in "Mr.Sampanth" and establishes herself. Rosie represents the more independent women of an India that is slowly changing under the impact of the west. Thus we can understand the obligations on Narayan's part and actually can see his development as a writer and social idealist through the journey of his heroines.

Another very important and controlling aspect of Rosie's life is her past. Her early identity as a Devdasi continues to haunt her and influence her actions all her life. She marries Marco and remains grateful to him in spite of all his misbehaviors as he erases her stigma of belonging to a devdasi family. Rosie's desire to serve food to her husband and Raju at the peak house during their happier days and "be the last to eat like a good housewife", can easily be understood as her delight in having a regular home-life, a common enough experience for many women but one which is usually denied to the Devdasis. It is her gratitude to an undeserving Marco for having married her in spite of her background that makes her lament her failed marriage forever. Narayan once writes in his autobiography "My Days" that Rosie's complex nature and self contradictory decisions is a result of her special social background.(6) In this respect Krishna Sen remarks that-

" Under no circumstances except as a temple dancer who has gained an entry into conventional social life, could there have been Rosie's unusual blend of rare independence and creativity with deep conservation and veneration for tradition."(Sen,60)(7)

Moreover we must remember the cultural hegemony of any patriarchal society, especially in Indian context. In Marxist philosophy, expounded by Italian theoretician Antonio Gramsci, the term cultural hegemony describes the domination of a culturally diverse society by the ruling class, who manipulate the culture of that society - the beliefs, perceptions, values-so that their ruling class would view looks like the universally valid dominant ideology that justifies the social, political and economic status quo as natural and perpetual for everyone, rather than as artificial social constructs that benefit only the ruling class.(8) Now in India, the identity of a child is determined just after the birth on the basis of gender, religion and caste. And if the child is a girl, her prime identity of being a 'female' remains her main identity for the rest of her life. From infancy she is taught to behave like a 'girl' and all the rules and norms set for the girl by the society. Just like a colonized in a colonial rule, who after a certain period of time starts believing in his/her inferior position, most of the girls too, in any patriarchal system becomes so saturated in their submissive roles set by the society that they think it to be right, inevitable, beneficial and justified for women. In fact it is women, even in today's India who impose those rules more brutally on other women than men. Rosie is no exception. Despite of all her education, assertive nature, love for her art and independent identity, she can't come out of this patriarchal hegemony.

But as Rosie's story rolls towards its end, we find a slow but steady transformation of her. When she realizes Raju's crime she calmly accepts the punishment that he gets. After remaining dependent to men throughout her life, she finally takes over all the works in her own hand and handles them perfectly.

"She swallowed her own words and went through her engagements, shepherding the musicians herself, with Mani's help, making al the railway arrangements, and so forth."(Narayan, 222)

Moreover after the judgment is given, after the departure of Raju, she starts pursuing her true Purpose of art. She is shown moving from strength to strength fulfilling her desire to become a true artist, rather than a performing machine. This transformation of Rosie is already indicated in her comparison with the King Cobra. In many cultures and mythologies the snake, which usually roughs off its 8ld scale and is reborn, is taken to be the emblem of the mystic, the mysterious, the psychic unconscious, the eternal renewal of the life on earth. Rosie too spiritually reborns and it is her dance that brings about her transformation. In fact Raju notices this change and calls a kind of reincarnation when she changes her name from Rosie to Nalini. It is her deep love for dance that jeopardizes her marital life and also brings about her separation with Raju. Paradoxically, it is this almost religious dedication towards dance that turns out to be the core strength of her life. Raju realizes and admits that-

"She would never stop dancing. She could not be able to stop. She would go from strength to strength... Neither Marco nor I had any place in her life, which had its own sustaining vitality and which she herself had underestimated all along."(Narayan, 223) (7)

Thus Rosie, at the end, portrays a very strong character. She has the ability to come out of the clutches of indifferent and exploitative men. She breaks the unfair social rules that try to bind her and her art. Most of all she establishes her own identity through her art. Thus she actually can be seen as the forerunner of today's confident and hardworking Indian women who are also sensitive and respectful towards their tradition. They take care of their work and family together. They follow the tradition but don't hesitate to break it and create new norms when it seems to block their path of self development. Rosie is truly a precursor of this new age 
Indian women.

\section{References}

[1]. Narayan, R.K., "The Guide"(1958), Indian Thought Publications, 2007.

[2]. Som Dev, The Guide: A Critical Appreciation, Prakash Book Depot,1982, Bareilly.

[3]. Spivak, Gayatri Chakraborty, "How to read a Culturally Different Book" in Barker, Hulme and Iverson eds., Colonial Discourse/Postcolonial Theory (1994), 126-150.

[4]. Narayan,R.K., "The Dark Room", Eye Publications, 1938

[5]. Narayan,R.K. "Mr. Sampanth-The Printer of Malgudi”, Eyre Publications, 1948

[6]. Narayan, R.K., "My Days”, Harper Collins,2013

[7]. Sen,Krishna, "Critical Essays on R.K.Narayan's 'The Guide', Orient Longman Private Ltd.2006.

[8]. Gramsci,Antonio, Ed.Joseph.A.Buttigieg, " The Prison Notebook", Columbia University Press, 2011

[9]. Narayan,R.K. "The Guide", Orient Longman Private Ltd.,2004,Delhi

[10]. Spivak, Gayatri Chakrabroty, "Can the Subaltern Speak?:Reflections on the History of An Idea, ed.Rosalind C.Morris, Columbia University Press,2010,New York 